\title{
Telecommuting Academics Within an Open Distance Education Environment of South Africa: More Content, Productive, and Healthy?
}

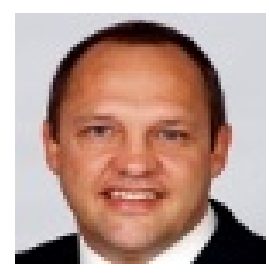

Deon Harold Tustin

University of South Africa

\section{Abstract}

Outside an academic setting, telecommuting has become fairly popular in recent years. However, research on telecommuting practices within a higher education environment is fairly sparse, especially within the higher distance education sphere. Drawing on existing literature on telecommuting and the outcome of a valuation study on the success of an experimental telecommuting programme at the largest distance education institution in South Africa, this article presents discerning findings on telecommuting practices. In fact, the research builds on evolutionary telecommuting assessment methods of the direct or indirect effect (work based) and affective impact (emotional) on multiple stakeholder groups. This holistic approach allowed for comparative analysis between telecommuting and nontelecommuting academics with regard to the impact of telecommuting practices. The research reveals high levels of support for telecommuting practices that are associated with high levels of work productivity and satisfaction, lower levels of emotional and physical fatigue, and reduced work stress, frustration, and overload. The study also reveals higher levels of student satisfaction with academic support from telecommuters than nontelecommuters. Overall, the critique presents insightful findings on telecommuting practices within an academic setting, which clearly signal a potential for a shift in the office culture of higher distance education institutions in the years to come. The study makes a significant contribution to a limited collection of empirical research on telecommuting practices within the higher distance education sector and guides institutions in refining and/or redefining future telecommuting strategies or programmes. 
Keywords: Telecommuting; nontelecommuting; working from home (WFH); working from office (WFO); open distance learning

\section{Introduction}

Since Nilles (1975) first defined telecommuting as «a type of working model wherein the employee, with some form of telecommunications device (most often a computer with some form of modem) works at a location other than the traditional centralised office,» the magnitude of research on this human resource practice has expanded considerably. Leading salient research on the international front specifically features investigations on the impact of this phenomenon on individuals and organisations. However, much of this past research is largely limited to the private sector. On the one hand, this suggests that telecommuting in the public sector has hitherto not been as widespread as in companies within the private sector. Alternatively, it can be assumed that there is insufficient information to allow for any pragmatic view on the extent to which this phenomenon affects higher distance education employees and institutions. Consequently, it seems reasonable to question whether the public sector, and particularly the open and distance higher education sector ${ }^{1}$, is suited to such work practices. Existing literature reveals that research to measure the potential for and impact of telecommuting practices on academics and higher distance education institutions is fairly sparse and largely limited to a few international examples. In this regard Athabasca University (Canada's Open University) published a literature review in 2006 on the potential benefits and shortcomings of telecommuting for academics as well as latent opportunities and challenges presented by telecommuting to open and distance education institutions. Although valuable, this research highlights the potential, rather than the actual impression, of telecommuting on academics and distance education institutions. The fact that the collective work of Athabasca University, as published by $\mathrm{Ng}$ (2006), largely resembles the outcome of earlier research chiefly conducted in the private sectors of the United States and the United Kingdom, presented sufficient rationale for conducting a local innovative empirical research study on telecommuting practices in the higher distance education sector of South Africa. Furthermore, the need for a contemporary study of this nature was motivated by the evolution of information technology and the potential for the distance education sector to benefit from these IT developments that present an ideal platform for telecommuting within an academic work environment where the practice of distance learning and research is most likely to benefit from prospective individual and institutional rewards stemming from telecommuting. By introducing a telecommuter programme in 2007 (Unisa, 2011), the University of South Africa (Unisa) is indisputably on the forefront of

1 Defined by the Department of Higher Education and Training as education that normally takes place in universities and other higher education institutions, both public and private, which offer qualifications on the Higher Education Qualifications Framework (HEQF) (DHET, 2012). 
testing the potential benefits of telecommuting practices in an open distance learning environment. For the first time since the telecommuting experiment was implemented, this article reports on the effects of the telecommuting programme on individual workers and the institution. It stands to reason that as the leading and largest open distance education institution on the African continent (Unisa, 2013), the selection of this institution as the investigative research unit for this evaluative research study was an obvious decision.

\section{Defining Telecommuting}

Besides the original description of telecommuting by Nilles (1975), exploratory research on telecommuting shows many common conceptions of this phenomenon. In this regard the following selected definitions provide a broader understanding of the concept (Yamini, Balakrishnan, Nguyen, \& Lopez, 1997; Fitzer, 1997; Igbaria, 1998; Federal Communications Commission, 2003; Martinez, 2004; Brown, 2010; Ipsos, 2011; MidAmerica Regional Council, 2013; Wikipedia, 2013):

- a significant workplace innovation that allows for an increasing portion of the workforce to work from home;

- an alternative work mode whereby some organizational employees spend part or all of their work week in isolation or at home;

- a work arrangement in which employees perform their regular work at a site other than the ordinary workplace, supported by technological connections;

- any arrangement in which an employee regularly performs officially assigned duties at home or other work sites geographically convenient to the residence of the employee;

- the use of collaborative technologies to reduce or entirely replace traditional commuting to the workplace;

- performing work for one's employer outside that employer's office, whether at home or some other remote location, as a substitute for working in the office.

To further distinguish between the de-localisation of work, Figure 1 outlines the main forms of telecommuting as cited in the work of Pinsonneault and Boisvert (1999). 


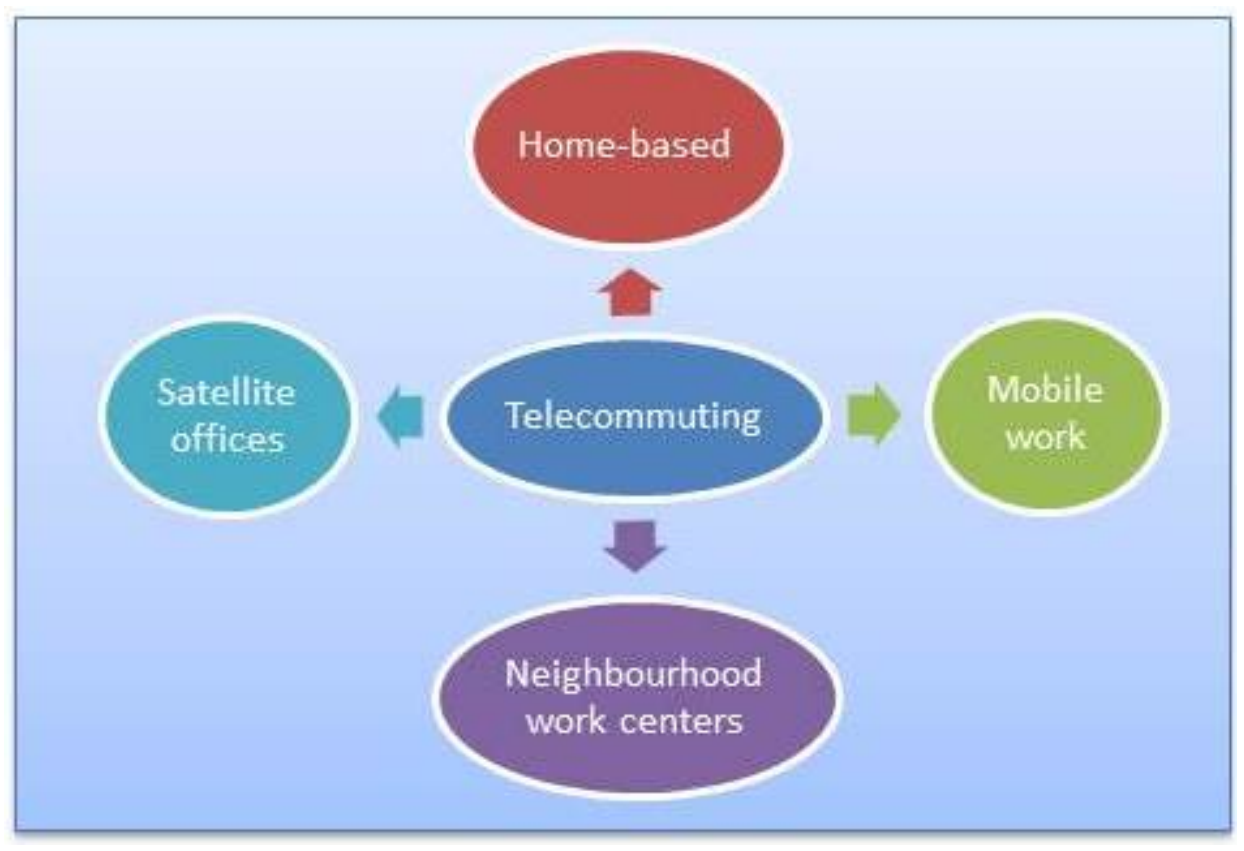

Figure 1. Leading forms of telecommuting.

A more extensive exposition of the four main forms of telecommuting follows below:

- Home-based telecommuting is usually performed in a dedicated area of the worker's place of residence. According to Gordon and Kelly (1986) and Nilles (1994), equipment installation fees are usually subsidised, entirely or in part, by the organisation.

- According to Doswell (1992) and Nilles (1994), satellite offices take the form of a small organisational affiliate generally located in proximity to residential areas where a telecommunications link with headquarters is permanently maintained.

- According to Olson (1987a), Di Martino and Wirth (1990), and Nilles (1994), neighbourhood work centres include private information centres that possess telecommunication tools that are shared by employees from various enterprises.

- Mobile work empowers employees with the capacity to perform activities in different places and in an ad-hoc fashion, such as in a car, plane, or hotel room. According to Davenport and Pearlson (1998) this form of telecommuting includes advantages such as enabling better and more personalised customer service.

Clearly, telecommuting is not restricted to any one particular form and is not limited to working from home on a full-time basis. Despite this awareness, the South African telecommuting baseline study was limited to measuring the impact of part-time homebased telecommuting as the telecommuting type tested by Unisa. However, prior to 
reflecting on the outcome of the study, the discussion proceeds with a holistic overview of the potential impact of telecommuting on individuals and organisations to set a sound methodological research foundation for telecommuting. In the absence of similar local research, this synopsis is based primarily on past international research on telecommuting practices within the private and public sectors. These are summarised in Exhibits 1 and 2.

Exhibit 1

Potential Advantages and Disadvantages of Telecommuting for Public and Private Sector Workers

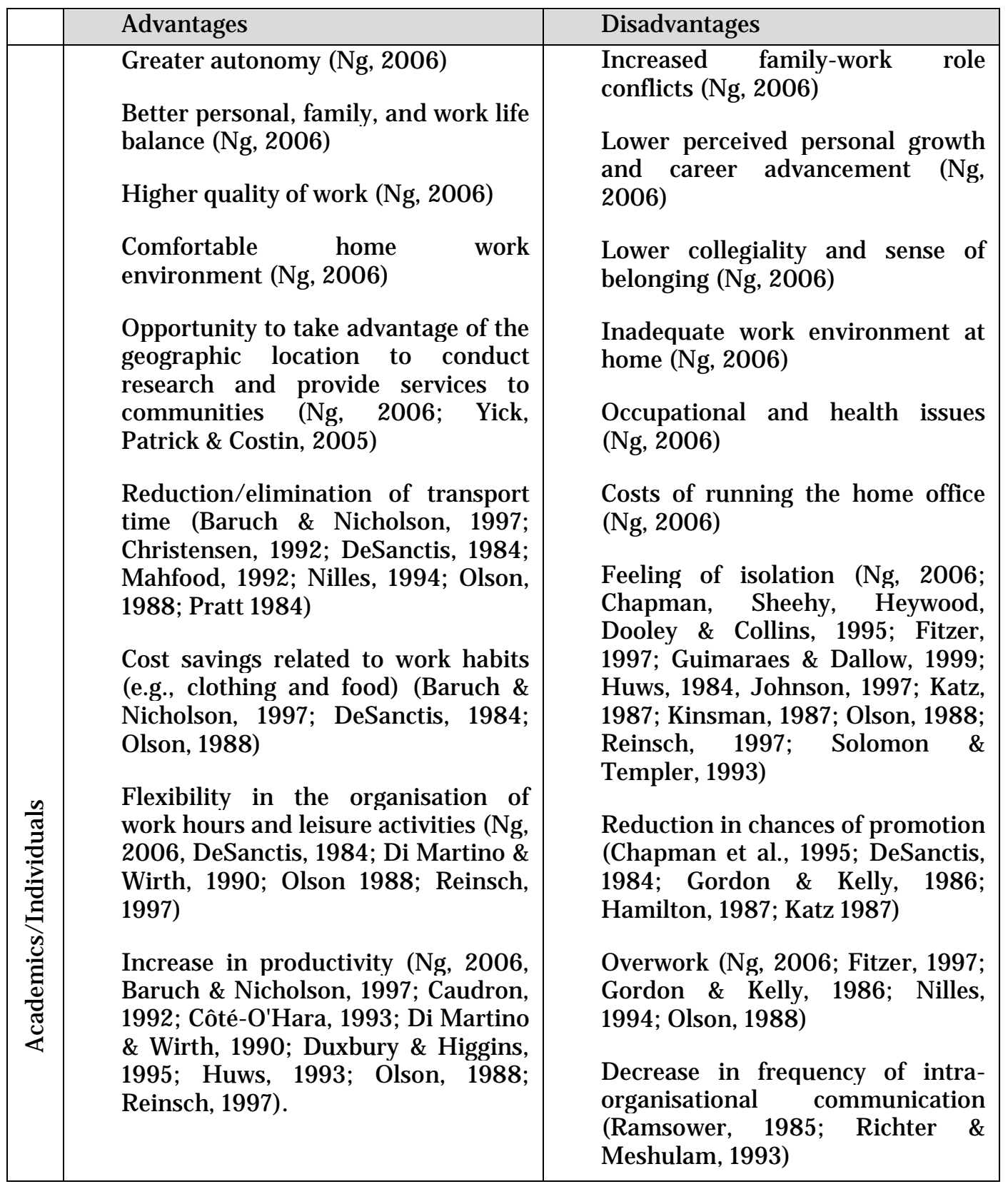


Exhibit 2

Potential Opportunities and Challenges for Public and Private Sector Entities

\begin{tabular}{|c|c|c|}
\hline & Opportunities & Challenges \\
\hline 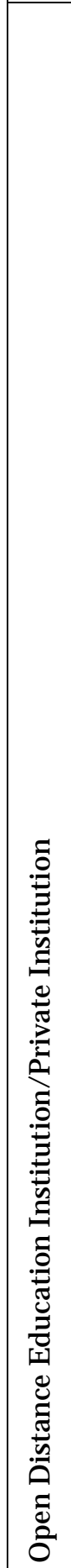 & $\begin{array}{l}\text { The ability to recruit employees from a } \\
\text { wider geographic area (Ng, 2006). } \\
\text { Better retention of competent staff (Ng, } \\
\text { 2006). } \\
\text { Lower absenteeism (Duxbury \& Higgins, } \\
\text { 1995; Fitzer, 1997; Greengard, 1995; } \\
\text { Gordon \& Kelly, 1986; Huws, 1993; } \\
\text { Kraut, 1987; Mahfood 1992; Nilles, 1994; } \\
\text { Wilkes, Frolick \& Urwiler, 1994) } \\
\text { Increased feelings of belonging } \\
\text { (Chapman et al., 1995) } \\
\text { Increase in loyalty (Caudron, 1992; Pratt, } \\
\text { 1984) } \\
\text { Increased ability to retain best employees } \\
\text { and attract new employees (Baig, 1995; } \\
\text { Christensen, 1992; Cross \& Raizman, } \\
\text { 1986; Davenport \& Pearlson, 1998; Di } \\
\text { Martino \&Wirth, 1990; Froggatt, 1998; } \\
\text { Gordon \& Kelly, 1986; Kraut, 1987; } \\
\text { Mahfood, 1992; Olson, 1987b, 1988; } \\
\text { Psikurich, 1996; Ruppel \& Harrington, } \\
\text { 1995) } \\
\text { Increased productivity (Alvi \& McIntyre, } \\
\text { 1993; Barthel, 1995; Baruch \& Nicholson, } \\
\text { 1997; Coté-O'Hara, 1993; Duxbury \& } \\
\text { Higgins, 1995; Gordon \& Kelly, 1986; } \\
\text { Huws, 1993; Katz, 1987; Kirkley, 1994; } \\
\text { Kraut, 1987; Mahfood, 1992; Nilles, 1994; } \\
\text { Trembly, 1998; Weiss, 1994; Xenakis, } \\
\text { 1997). } \\
\text { Decrease office rental costs; decreases } \\
\text { overcrowding (Apgar, 1998; Christensen, } \\
\text { 1992; Davenport \& Pearlson, 1998; } \\
\text { Gordon \& Kelly, 1986; Katz, 1987; } \\
\text { Kirkley, 1994; Kraut, 1987; Mahfood, } \\
\text { 1992; McCune, 1998; Nilles, 1994, Olson, } \\
\text { 1987b) } \\
\text { Quicker responsiveness to customers and } \\
\text { to unexpected events such as natural } \\
\text { disasters (Eldib \& Minoli, 1995; Fitzer, } \\
\text { 1997; Katz 1987; Korzeniowski, 1997; } \\
\text { Nilles 1994); } \\
\text { Increased organisational flexibility } \\
\text { (Nilles, 1994; Olson 1987b; Ruppel \& } \\
\text { Harrington, 1995) } \\
\text { Better usage of information systems } \\
\text { (Gordon \& Kelly, 1986, Hamilton, 1987) }\end{array}$ & $\begin{array}{l}\text { Monitoring and evaluating } \\
\text { performance based on results } \\
\text { rather than physical presence or } \\
\text { visibility (Ng, 2006). } \\
\text { Ensuring adequate and } \\
\text { appropriate information and } \\
\text { telecommunication technologies } \\
\text { are equipped in home offices, and } \\
\text { effective training and support are } \\
\text { provided (Ng, 2006). } \\
\text { Ensuring telecommuting } \\
\text { academics have an adequate, safe } \\
\text { and healthy work environment } \\
\text { (Ng, 2006). } \\
\text { Providing space for research to } \\
\text { those academics with specific } \\
\text { spatial needs - e.g., laboratories } \\
\text { (Ng, 2006). } \\
\text { Creating team synergy, } \\
\text { transmitting organisation culture, } \\
\text { and promoting a feeling of } \\
\text { belonging to the institution (Ng, } \\
\text { 2006). } \\
\text { Retaining competent staff and } \\
\text { competing with traditional } \\
\text { institutions for academics } \\
\text { experienced or interested in } \\
\text { online teaching (Ng, 2006). } \\
\text { Greater absence of best employees } \\
\text { from the office (Gordon \& Kelly, } \\
\text { 1986; J ohnson, 1997) } \\
\text { Loss of synergy in the } \\
\text { organisation (Fitzer, 1997; } \\
\text { Hamilton, 1987) } \\
\text { Difficulty in managing } \\
\text { telecommuting makes supervisors } \\
\text { dissatisfied (Christensen, 1992; } \\
\text { Fitzer, 1997; Gordon \& Kelly, } \\
\text { 1986; Katz, 1987; Nilles, 1994; } \\
\text { Solomon \& Templer, 1993) } \\
\text { Increased data security concerns } \\
\text { (Gray, Hodson \& Gordon, 1993; } \\
\text { Katz 1987) } \\
\text { Difficulty in objectively evaluating } \\
\text { the financial benefits of } \\
\text { telecommuting (Alvi \& McIntyre, } \\
\text { 1993, Doswell, 1992) }\end{array}$ \\
\hline
\end{tabular}


Exhibits 1 and 2 display the plethora of previous, mostly international, research on telecommuting. However, the synopses also affirm a clear lack of similar local research and present sufficient rationale for an original baseline evaluation study for South Africa.

\section{Research Scope and Aim}

Most past models and theories about telecommuting have concentrated mainly on the telecommuter's experiences and perspective. In fact, much of prior research on telecommuting has been weakened by two assumptions, namely that telecommuters form a homogenous group and that telecommuting involves only the telecommuter (Bailey \& Kurland, 2002; McCloskey \& Igbaria, 2003). Also, aligned with the views of Bailey and Kurland (2002), Cooper and Kurland (2002), Golden (2007), Duxbury and Neufield (1999), Fritz, Narasimhan, and Rhee (1998), and McCloskey and Igbaria (2003), few studies have examined the potential impacts of telecommuting holistically, or investigated it from a nontelecommuter and/or student perspective and how this practice affects work outcomes and student satisfaction. With the foregoing as background, this article reflects on the aim, scope, and outcome of the first higher distance education telecommuting study in South Africa that was conducted among both home- and office-based academics, managers of academic departments, and students who received academic support from part-time (home-based) telecommuting academics and/ or full-time (office-based) nontelecommuting academics.

With the aforementioned in mind, this research study included four distinctive interdependent key stakeholder groups for which separate research goals and instruments were designed. The specific study objectives for the relevant stakeholder groups are clarified in the subsections below.

\section{Academics working from home (WFH).}

This subsurvey was conducted among senior telecommuting academics (professors and associate professors), having been officially granted permission to work part-time from home. More specifically, this substudy aimed to determine telecommuting academics' experiences and perspectives regarding the working from home (WFH) initiative.

\section{Academics working from office (WFO).}

This subsurvey was conducted among two office-bound academic groups. Firstly, the study targeted senior academics (professors and associate professors) that are officebased (nontelecommuters) and who are employed in the same department as an academic working from home. The primary aim of this secondary study was to establish the attitudes and perceptions of onsite staff regarding telecommuting and to determine the perceived effect (work impact) and affect (emotions/attitudes) of telecommuting on office-based workers. Secondly the study also targeted onsite staff employed in an academic department without an academic WFH. Overall, the nontelecommuter study 
aimed to provide insights into some of the organisational impacts of telecommuting and the implications for nontelecommuters.

\section{Line managers.}

This subsurvey was conducted primarily among the supervisors of senior academics (professors and associate professors) who were granted permission to work from home on a part-time basis. The aim of the study focusing on line managers was to determine the perceptions of supervisors of the impact of telecommuting on the staff morale of onand off-site workers and the operations of the department. To allow supervisors whose departments do not host an academic WFH an opportunity to voice their opinions on the WFH initiative, this subpopulation segment was also included in the line manager's study.

\section{Students.}

This subsurvey was conducted among under- and postgraduate students regarding their satisfaction with academic support offered by telecommuting academics (professors and associate professors) and nontelecommuting (office-based) academics working in the same department and lecturing similar or dissimilar modules to those lectured by academic telecommuters.

\section{Method}

\section{Sampling Methodology}

Whereas a census approach was used to conduct the surveys among academic staff members, a judgemental sampling approach was used to select students to participate in the student satisfaction survey. The judgemental approach largely reduced nonresponse errors that could have had negative consequences for the entire study. Consequently, it was logical to use the academic departments hosting an academic telecommuter as basis for constructing the sampling unit (academic departments) and sampling element (staff and students) frames for the study. More specifically, this approach supported constructive research participation by relevant key stakeholder groups.

\section{Sample Size}

Table 1 displays the sample size for each research stakeholder group who participated in the telecommuter evaluation study. It is important to note that only 33 academic departments hosted senior academic telecommuters who formed the basis for the investigation. In total, 76 Unisa academics telecommuted during the trial period of 
which almost half participated in the study. In total, 154 academics and 156 students were included in the study.

Table 1

Research Stakeholder Sample Size

\begin{tabular}{|l|l|}
\hline Research stakeholder group & $\mathrm{n}$ \\
\hline Academic telecommuters & 36 \\
\hline Academic nontelecommuters & 102 \\
\hline Line managers & 16 \\
\hline Students & 156 \\
\hline
\end{tabular}

\section{Survey Instruments and Fieldwork Administration}

After constructing the research instruments for the various survey groups, these were transformed into web-based survey formats. For the surveys among the academic groups, an email invitation was sent to all sampling elements, requesting them to retrieve the questionnaire via a web link and to submit the survey once completed. The academic surveys were administrated in conjunction with the student satisfaction survey conducted over a two-week survey period.

The research instruments designed for all four participating stakeholder groups mainly used a 5-point agreement rating scale for a selection of predetermined statements. The number of variables for each stakeholder group for selected constructs is displayed in Table 2 .

Table 2

Research Construct and Number of Items

\begin{tabular}{|l|l|l|}
\hline Stakeholder group & Construct & $\begin{array}{l}\text { Number of } \\
\text { items }\end{array}$ \\
\hline Telecommuting academics & $\begin{array}{l}\text { Telecommuting benefits } \\
\text { Effect and affective impact of } \\
\text { telecommuting }\end{array}$ & $\begin{array}{l}21 \\
27\end{array}$ \\
\hline $\begin{array}{l}\text { Nontelecommuting } \\
\text { academics }\end{array}$ & $\begin{array}{l}\text { Effect and affective impact of } \\
\text { telecommuting }\end{array}$ & 46 \\
\hline Line managers & $\begin{array}{l}\text { Operational impact of } \\
\text { telecommuting }\end{array}$ & 72 \\
\hline Students & Academic student support & 17 \\
\hline
\end{tabular}


It is important to note that participation in the research study for all stakeholder groups was voluntary and depended on participant consent. All participants were informed of the purpose of this research, the confidentiality with which information was received, dealt with, and stored, the right to terminate participation, and what to expect from the interview.

\section{Data Editing, Cleaning, Analysis, and Reliability}

Once the electronic data for all four surveys were captured, the data were edited and cleaned for data analysis and interpretation purposes. All analysis was conducted using the SPSS software statistical analysis package. The analysis also included data validation, the outcome of which is summarised in Table 3. More specifically, Cronbach's alpha was used as a tool to determine the internal consistency of items in the telecommuter survey instrument to gauge its reliability.

Table 3

Reliability Statistics

\begin{tabular}{|l|l|}
\hline Stakeholder group and research constructs & Alpha coefficients \\
\hline $\begin{array}{c}\text { Telecommuting academics } \\
\bullet \quad \text { Telecommuting benefits } \\
\bullet \quad \text { Effect and affective impact of telecommuting }\end{array}$ & $\begin{array}{l}\alpha=0.863 \\
\alpha=0.750\end{array}$ \\
\hline $\begin{array}{l}\text { Nontelecommuting academics } \\
\text { Effect and affective impact of telecommuting }\end{array}$ & $\alpha=0.973$ \\
\hline $\begin{array}{c}\text { Line managers } \\
\text { Operational impact of telecommuting }\end{array}$ & $\alpha=0.964$ \\
\hline $\begin{array}{l}\text { Students } \\
\bullet \quad \text { Academic student support }\end{array}$ & $\alpha=0.980$ \\
\hline
\end{tabular}

In general, alpha coefficients ( $\alpha$ ) range in value from 0 to 1 and may be used to describe the reliability of factors extracted from, among others, scale questions (i.e., rating scale: $1=$ totally disagree, $5=$ totally agree). The higher the score, the more reliable the generated scale is. Nunnaly (1978) and Kline (1999) have indicated 0.7000 to be an acceptable reliability coefficient but lower thresholds are sometimes used in literature. The fact that all Cronbach alpha values exceed the 0.7000 threshold in Table 3 therefore presents sufficient evidence that the listed telecommuting constructs in the four subsurveys are reliable future predictor variables. Also, the overall consensus and consistency of responses across all four different stakeholder groups further support the reliability and validity of the survey findings. 


\section{Research Analysis}

The perceptions and experiences of telecommuting and nontelecommuting academics, managers, and students are analysed in this section essentially in a descriptive analysis format.

\section{Part-Time Home-Based Telecommuting Survey}

This section reveals the outcome of the survey among telecommuting academics.

\section{Satisfaction, benefits, and challenges.}

In an introductory section, telecommuting academics were requested to rate aspects that they enjoy most when working from home. These ratings were transformed into a single enjoyment index of which the final result is displayed in Figure 2.

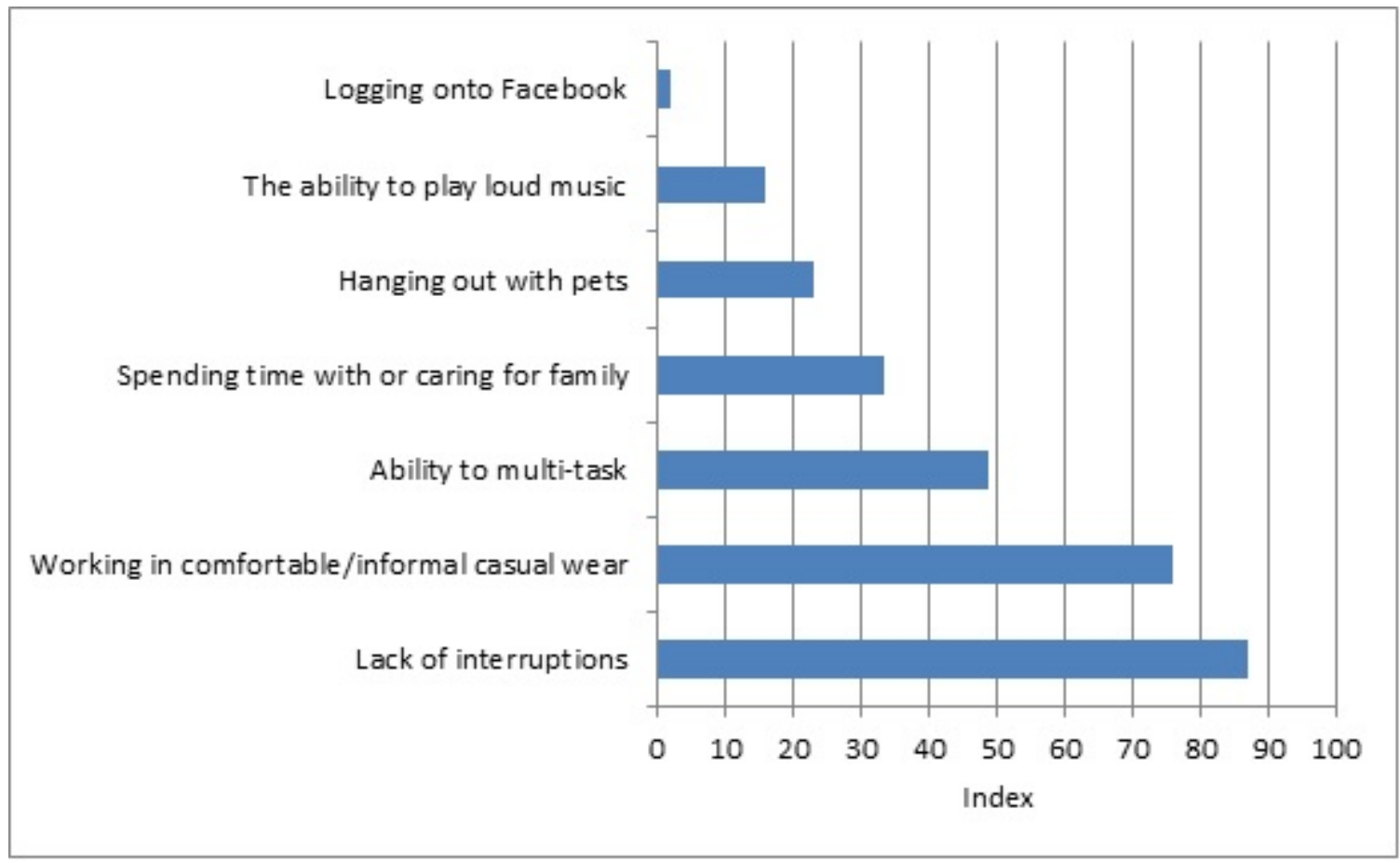

Figure 2. Enjoyment rankings of academic telecommuters.

Figure 2 shows that telecommuter academics appreciate telecommuting as this practice presents ideal opportunities for fewer work interruptions and to work in comfort or multi-task. The fact that all academic telecommuters indicated that they are extremely (80.6\%) or somewhat (19.4\%) satisfied with working from home further affirms high levels of pro-telecommuting sentiments. In fact, when analysing the claimed benefits experienced by academic telecommuters, it is evident that telecommuting increases work productivity, concentration, and flexibility. These views are displayed in Table 4, 
which summarises the outcome of the levels of agreement with the benefits of telecommuting experienced by academic telecommuters. The analysis shows the agreement index scores for the respective telecommuting benefits compiled from the agreement rating scores of academic telecommuters ranging from totally disagree (rating $=1$ ) to totally agree (rating $=5$ ). It is important to note that scores closer to '100' represent relatively higher levels of agreement.

Table 4

Telecommuting Benefits Agreement Index

\begin{tabular}{|l|l|}
\hline Benefit & $\begin{array}{l}\text { Index } \\
\text { scores }\end{array}$ \\
\hline Increased productivity & 96.53 \\
\hline Stronger focus on work & 95.14 \\
\hline Increased work flexibility & 93.75 \\
\hline Shorter travel time & 92.65 \\
\hline Lower travel costs & 91.67 \\
\hline Avoid interruptions and distractions & 88.19 \\
\hline J ob satisfaction & 87.86 \\
\hline Save time (more workdays available otherwise spent commuting) & 87.86 \\
\hline Less focus on office politics & 86.81 \\
\hline Improved overall quality of life & 83.09 \\
\hline Improved employee morale & 82.58 \\
\hline Greater freedom & 81.94 \\
\hline Improved management of workload & 79.17 \\
\hline Decreased carbon footprint & 78.03 \\
\hline Improved work-life balance & 77.14 \\
\hline Enhanced ability to meet deadlines & 73.57 \\
\hline Less absenteeism & 71.97 \\
\hline Organisational loyalty and belonging & 70.71 \\
\hline Reduced work-related stress & 64.39 \\
\hline More time for oneself & 48.57 \\
\hline Spending more time with family/ children & 45.97 \\
\hline
\end{tabular}

In general, academic telecommuters confirmed that they get more work done and concentrate better at home than at the office, which also contributes to the improvement in overall work quality and healthier (eating and lowered stress) workers. The work-related effects of telecommuting practices that echo these encouraging findings are displayed in Figure 3. 


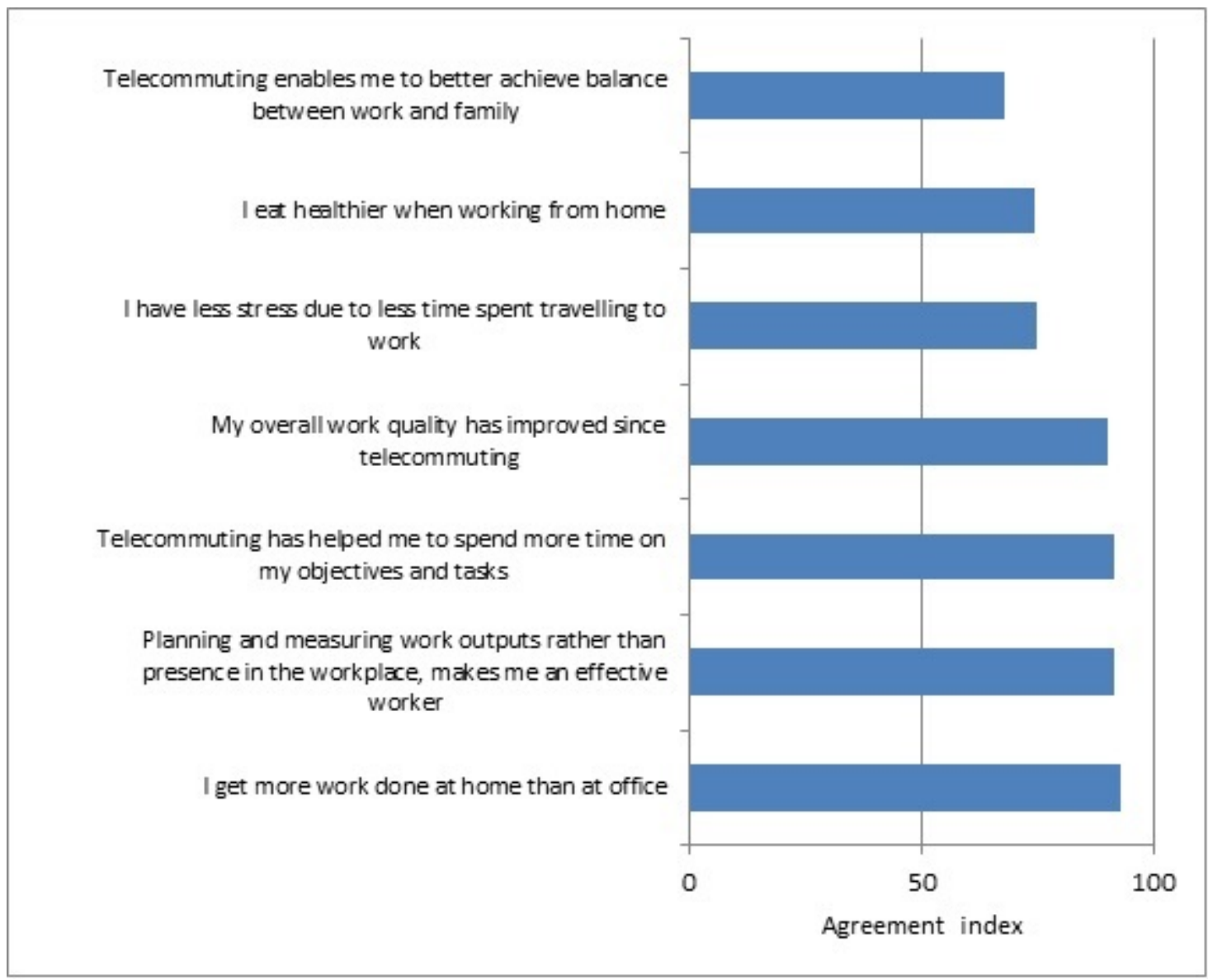

Figure 3. Work effect of telecommuting on academic telecommuters.

Despite many benefits experienced by academic telecommuters, $76.2 \%$ also indicated that the major challenge that they experience is network connectivity to allow digital connection. A further $19.0 \%$ of respondents cited the lack of office equipment as a major impediment to telecommuting while $4.8 \%$ mentioned that bad posture, as a result of working at makeshift home offices, makes telecommuting less attractive. Social interaction with colleagues at work was also cited by most academic telecommuters as a key factor missed most about not working at the office. The challenges posed by telecommuting to telecommuters are summarised in Figure 4. 


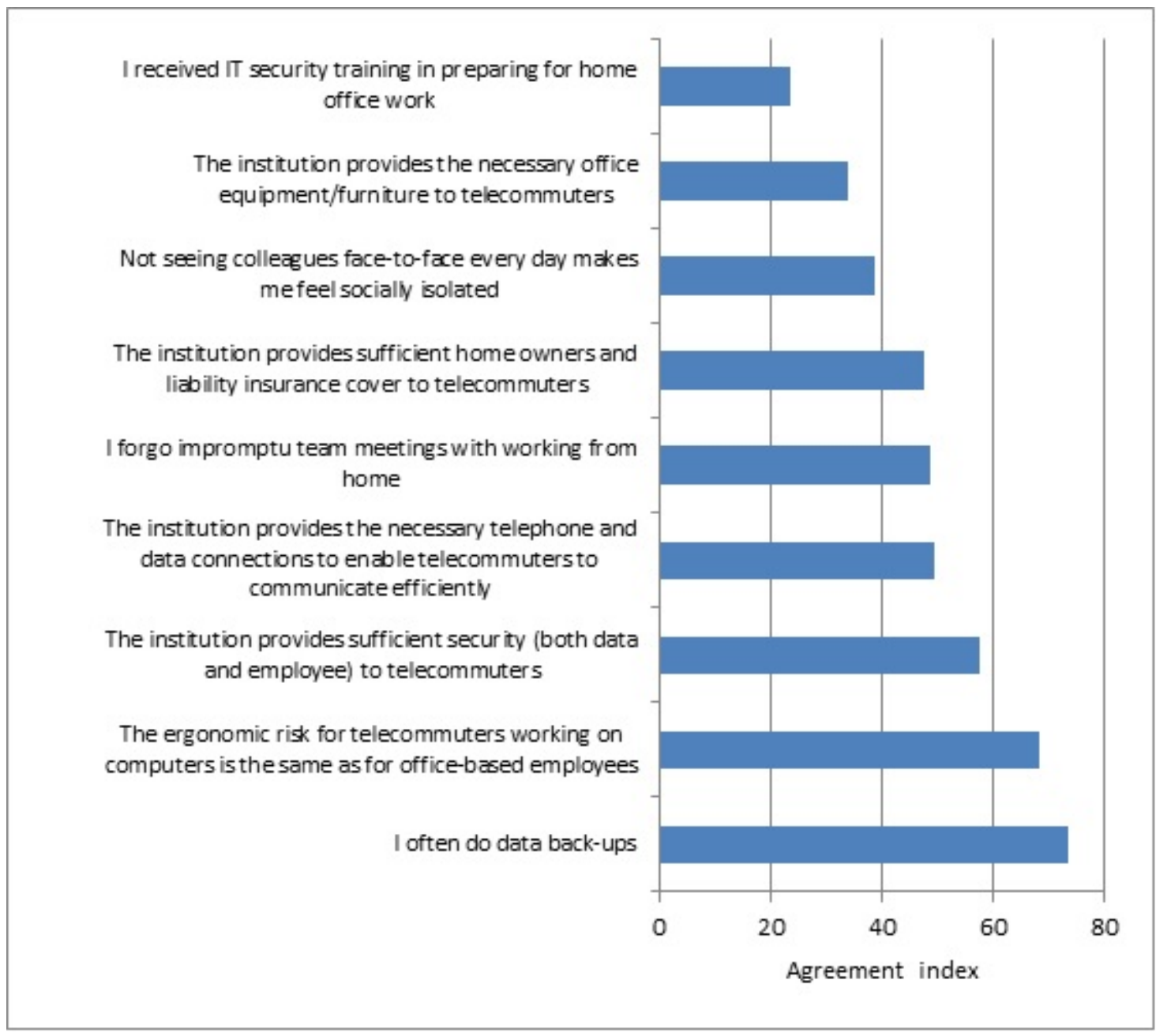

Figure 4. Challenges faced by academic telecommuters.

The key findings emerging from the academic telecommuter survey presented sufficient evidence of high levels of support for telecommuting practices within a true open distance learning environment. Experienced senior academic staff clearly articulated that telecommuting practices are very beneficial for creating a productive, dedicated, economical, flexible, and satisfied workforce. Also, telecommuters seem very positive about telecommuting as a mechanism to ease work stress and afford more valuable time with family members. However, key challenges remaining for open distance education institutions who wish to expand telecommuting practices are more dedicated attention to improved network connectivity as well as security, insurance, and infrastructure support aspects relevant to telecommuting. 


\section{Office-Based Telecommuting Survey}

This section reveals the outcome of the telecommuter survey among nontelecommuting academics. When focusing on this stakeholder group, it is important to note from previous international research that telecommuting may change the scope and amount of work of those remaining in the office (see Kugelmass, 1995; Gordon, 2006; Reinsch, 1997; Chapman, Sheehy, Heywood, Dooley, \& Collins, 1995; Harrington \& Ruppel, 1999). To determine the effect of telecommuting on the workload of nontelecommuting (office-based) staff, a total of over 100 office-based academics participated in the telecommuter study. These academics were requested to reflect on the affective impact and effect of telecommuting practices and to indicate whether they experienced any additional work responsibilities in cases where telecommuting colleagues are absent from the office. Figure 5 reflects the expanded work responsibilities experienced by just more than half (57.5\%) of the office staff.

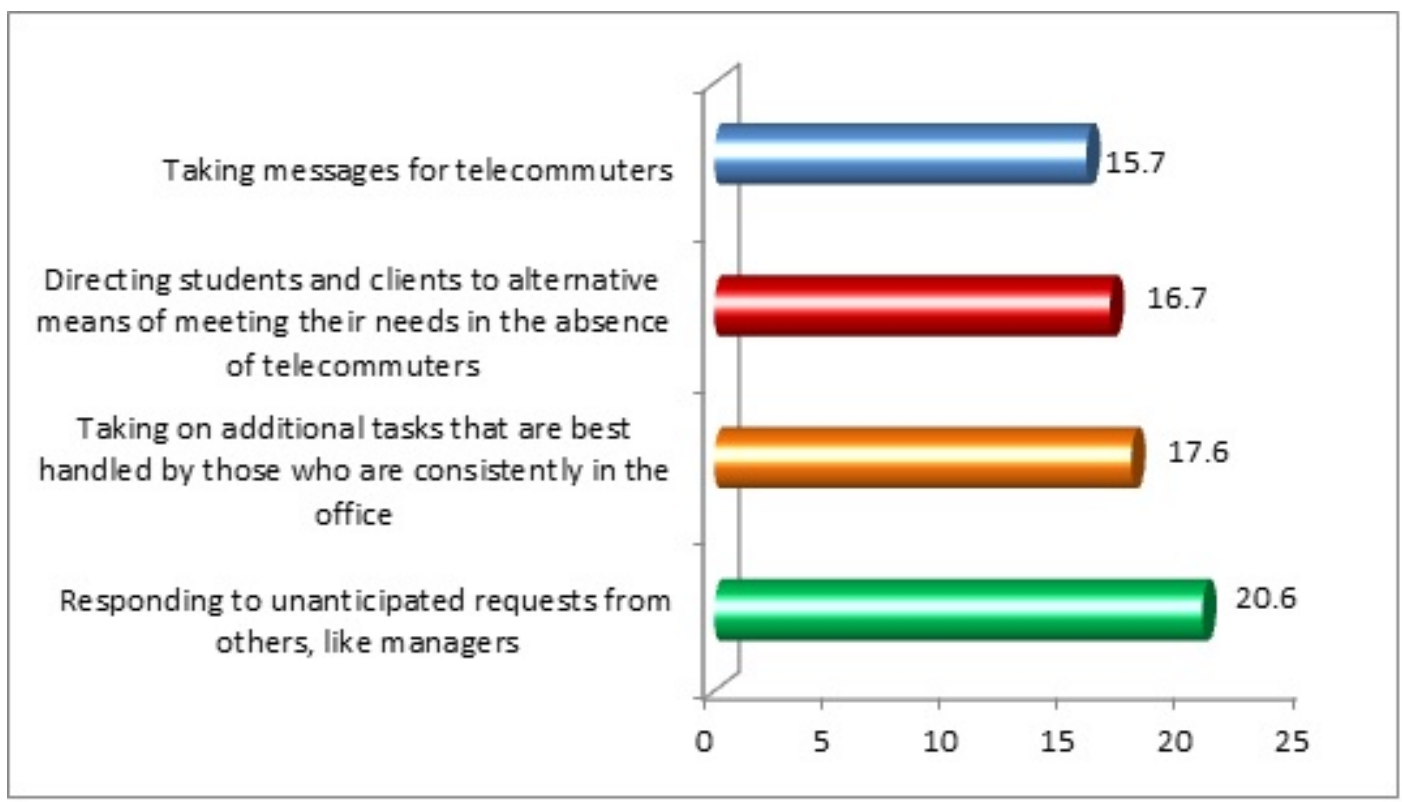

Figure 5. Effect of co-workers' telecommuting on office-based workers. 
It is clear from Figure 5 that approximately a fifth of office workers have to respond more frequently to unanticipated requests from other staff like managers due to telecommuters being absent from the office. Approximately one in every 10 office staff indicated that he/ she has to take messages for telecommuters (15.7\%) or direct students/ clients in the absence of telecommuters.

\section{Perceptions of telecommuting.}

The key section of the research questionnaire measured the perceptions of office workers regarding telecommuting practices. Office-based workers were requested to indicate their level of agreement with 46 predetermined statements using a 5-point Likert response scale where $1=$ totally disagree and $5=$ totally agree. For analysis purposes, the ratings of respondents were transformed into average agreement indices that are summarised in Table 5 according to the effect (work based) and affective impact (emotional) of telecommuting on office-based workers. Clearly, most office-based academics are content with the access to and productivity of telecommuting academics while some are fairly indifferent about the impact of telecommuting on the workload of office-based workers, teamwork, and shared work responsibility. It would seem that this impartial stance has not roused significant resentment or jealousy of telecommuters among office-based workers. In terms of the effect of telecommuting, office-based workers also have not experienced significant adjustments to their own work schedule, workload, or productivity since the introduction of telecommuting practices in academic departments. 
Table 5

Effect and Affective Impact of Telecommuting Practices on Office-Based Academics

\begin{tabular}{|c|c|c|}
\hline & Statement & $\begin{array}{l}\text { Weighted } \\
\text { index }\end{array}$ \\
\hline \multirow{13}{*}{ 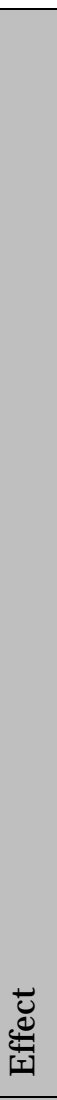 } & $\begin{array}{l}\text { Telecommuters make effective use of technologies such as email to } \\
\text { communicate work-related issues to office-based co-workers }\end{array}$ & 74.26 \\
\hline & Telecommuters are equally or immediately accessible & 62.31 \\
\hline & $\begin{array}{l}\text { I am astonished about the amount and quality of work completed by } \\
\text { off-site workers }\end{array}$ & 57.09 \\
\hline & $\begin{array}{l}\text { The work distribution between telecommuters and nontelecommuters } \\
\text { is equal }\end{array}$ & 51.12 \\
\hline & $\begin{array}{l}\text { Telecommuting has a negative influence on teamwork, particularly in } \\
\text { terms of peer interaction and communication effectiveness between } \\
\text { telecommuters and their co-workers }\end{array}$ & 48.48 \\
\hline & $\begin{array}{l}\text { Scheduling and planning meetings has become more problematic } \\
\text { since appointing PWFH and decreases flexibility }\end{array}$ & 46.74 \\
\hline & $\begin{array}{l}\text { I tend to make adjustments in my work patterns to compensate for the } \\
\text { absence of telecommuting co-workers and managers }\end{array}$ & 43.36 \\
\hline & $\begin{array}{l}\text { I simply proceed with my work activities without the full input and } \\
\text { advice of telecommuting co-workers, thus increasing the risk of } \\
\text { potential strife and misunderstandings or poor decisions }\end{array}$ & 41.67 \\
\hline & $\begin{array}{l}\text { The flexibility in conducting my work activities has decreased due to } \\
\text { greater restrictions when coordinating and adjusting own duties and } \\
\text { schedules to accommodate telecommuters }\end{array}$ & 39.02 \\
\hline & $\begin{array}{l}\text { My scope and amount of work has changed since some staff were } \\
\text { permitted to telecommute }\end{array}$ & 38.24 \\
\hline & My own productivity decreases when co-workers telecommute & 33.09 \\
\hline & $\begin{array}{l}\text { Conflict with telecommuting co-workers has increased since they } \\
\text { began to work from home }\end{array}$ & 30.60 \\
\hline & $\begin{array}{l}\text { Since the department has appointed telecommuters my manager's } \\
\text { attention towards me has gradually tapered off }\end{array}$ & 27.50 \\
\hline \multirow{5}{*}{ 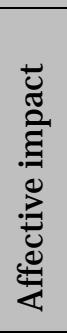 } & $\begin{array}{l}\text { I am highly frustrated having to contend with shifting patterns, } \\
\text { interruptions and disruptions due to 'missing' colleagues }\end{array}$ & 43.31 \\
\hline & $\begin{array}{l}\text { I think highly of telework/ telecommuting as long as it does not } \\
\text { negatively affect my work or does not affect teamwork }\end{array}$ & 71.69 \\
\hline & $\begin{array}{l}\text { I feel marginalised or deprived of the advantages (i.e. resources) that } \\
\text { telecommuters receive }\end{array}$ & 40.00 \\
\hline & I resent telecommuters & 28.47 \\
\hline & I am jealous of telecommuters & 21.13 \\
\hline
\end{tabular}




\section{Comparative Analysis between Telecommuting and Nontelecommuting Academics}

To begin with the comparative analysis between telecommuting and nontelecommuting academics, Table 6 firstly displays the magnitude of the agreement indices for the key drivers of job satisfaction for both academic groups.

Table 6

Key Factors Driving J ob Satisfaction of Telecommuting and Nontelecommuting Academics

\begin{tabular}{|l|l|l|}
\hline \multirow{2}{*}{ Factor } & Agreement index \\
\cline { 2 - 3 } & $\begin{array}{l}\text { Telecommuting } \\
\text { academics }\end{array}$ & $\begin{array}{l}\text { Nontelecommuting } \\
\text { academics }\end{array}$ \\
\hline Flexibility of working at home/ outside the office & 92.97 & 81.52 \\
\hline Flexibility to decide how work is done & 91.43 & 84.93 \\
\hline Quality of work environment & 90.00 & 81.06 \\
\hline Flexibility of working hours & 89.29 & 85.29 \\
\hline Quality of computer, mobile and other tools & 89.29 & 84.70 \\
\hline Fair human resource distribution & 84.09 & 76.49 \\
\hline Quality of line manager & 83.09 & 79.10 \\
\hline Salary & 82.86 & 75.37 \\
\hline Relationship with line manager & 81.62 & 76.49 \\
\hline Rewards/ benefits & 81.25 & 78.73 \\
\hline Promotions & 76.61 & 74.25 \\
\hline Time to commute to work & 74.26 & 78.68 \\
\hline
\end{tabular}

It is clear from the rank-order analysis presented in Table 6 that flexibility of working at home/ outside the office, flexibility to decide how work is done, and the quality of the work environment are the key determinants of job satisfaction of both academic groups. In turn, rewards/benefits, relationship with line manager, promotions, and time to commute to work are among the least important determinants of job satisfaction.

A further key finding emerging from the telecommuting study is that telecommuting academics generally seem more productive and happier than nontelecommuters and also tend to experience lower levels of fatigue and work frustration. The comparative indices shown in Table 7 for the work symptoms experienced by telecommuters and nontelecommuters clearly illustrate these pertinent findings. 
Table 7

Work Symptoms Experiences by Telecommuting and Nontelecommuting Academics

\begin{tabular}{|l|l|l|}
\hline Statement & $\begin{array}{l}\text { Telecommuters } \\
\text { index }\end{array}$ & $\begin{array}{l}\text { Nontelecommuters } \\
\text { index }\end{array}$ \\
\hline Emotional fatique & 40.0 & 73.9 \\
\hline Physical fatique & 32.3 & 69.2 \\
\hline Work satisfaction & 85.7 & 58.2 \\
\hline Work frustration & 60.0 & 86.9 \\
\hline Work overload & 74.3 & 95.6 \\
\hline
\end{tabular}

The findings displayed in Table 7 closely resemble a 2012 USA (TeamViewer ${ }^{\circledR}$, 2012) study indicating that employees in WFH arrangements, whether part- or full-time, report less emotional and physical fatigue than on-site workers. When reflecting on productivity in particular, it is also evident from the 2011 International Ipsos Telecommuting Survey that $70.0 \%$ of respondents confirmed that telecommuters are more productive than those who work at the office (Ipsos, 2011). Respective figures for Argentina (topping the list) and Japan (bottom of the list) were $77.0 \%$ and $44.0 \%$. Internationally, the average proportion of respondents that regard telecommuters as more productive stands at $65.0 \%$.

\section{Managers' Perceptions of Telecommuting}

The core of the research instrument designed for line managers/supervisors was devoted to a series of predetermined statements related to the operational and employee impact of telecommuting. Against this background, supervisors were requested to supply their level of agreement with 72 different statements where $1=$ totally disagree and $5=$ totally agree. Items recording the highest and lowest agreement scores among line managers are displayed in Exhibit 3. 
Exhibit 3

Top and Bottom Agreement Scores of Managers on Telecommuting Practices

\begin{tabular}{|c|c|}
\hline 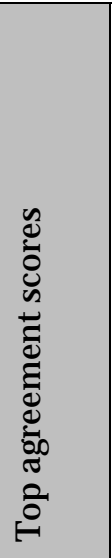 & $\begin{array}{l}\text { - Not all academics have the makeup to be a telecommuter } \\
\text { - The right person could telecommute regardless of his/ her job duties } \\
\text { - } \text { productive hours } \\
\text { - Unisa employees appreciate the flexibility of remote working } \\
\text { - Telecommuting benefits employee retention and attraction } \\
\text { - Telecommuting saves office space } \\
\text { - } \text { telecomformuting (work from home) } \\
\text { - Since the implementation of the PWFH Directive, telecommuting } \\
\text { employees work with fewer distractions }\end{array}$ \\
\hline 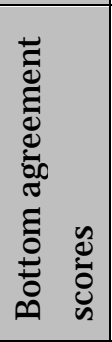 & $\begin{array}{l}\text { - It is difficult to monitor telecommuting employees } \\
\text { - All academics are responsible enough to be telecommuters } \\
\text { - Uncertainty whether employees really work when they are at home during } \\
\text { office hours } \\
\text { - } \text { Concerned about getting a full day of work from a telecommuter } \\
\text { - It is difficult to measure the productivity of telecommuters when they are } \\
\text { - } \text { not in the office } \\
\text { Telecommuting is unfair towards office-based workers }\end{array}$ \\
\hline
\end{tabular}

From the analysis presented in Exhibit 3, it is clear that the physical absence of telecommuters presents a fair measure of challenges to managers in terms of monitoring the work performance of telecommuting staff. Also, managers are clear in their views that not all academics are suitable for telecommuting. Despite this view, line managers confessed that telecommuting practices are most likely to result in more flexibility and dedicated employees. 


\section{Impact of Telecommuting on Management and Nontelecommuter workload.}

To measure the effect of telecommuting on the workload of managers, professional and support staff, the survey also requested line managers/supervisors to indicate whether the workload across these different staff categories had increased or remained unchanged since implementing telecommuting practices in the academic department. The outcome of this research finding is presented in Table 8.

Table 8

Effect of Telecommuting on the Workload of Managers and Nontelecommuters

\begin{tabular}{|l|l|l|l|l|}
\hline Designation & $\begin{array}{l}\text { Increased } \\
\%\end{array}$ & $\begin{array}{l}\text { Increased } \\
\text { slightly } \\
\%\end{array}$ & $\begin{array}{l}\text { Increased } \\
\text { substantially } \\
\%\end{array}$ & $\begin{array}{l}\text { No } \\
\text { change } \\
\%\end{array}$ \\
\hline Management & 13.3 & 20.0 & - & 66.7 \\
\hline Professional staff & 14.3 & 21.4 & 7.1 & 57.1 \\
\hline Support staff & 13.3 & 13.3 & 13.3 & 60.0 \\
\hline
\end{tabular}

It is clear from Table 8 that approximately $60 \%$ of the managers/ supervisors indicated that telecommuting had no significant impact on the workload of nontelecommuters. One in every five line managers indicated that the workload of management $(20.0 \%)$ and professional staff (21.4\%) had increased slightly. Just more than $10.0 \%$ of line managers indicated that the workload of support staff had increased substantially as a result of telecommuting. Most importantly, Table 8 shows that two-thirds of managers experienced no change in their own workload.

It was also evident from the line manager survey that telecommuting is an ideal strategy to retain and attract staff. Line managers were also of the opinion that telecommuting practices reduce stress and that telecommuters are as trustworthy as office-based workers. Line managers were also confident in their views that there is no resentment between telecommuters and nontelecommuters and that telecommuters are not necessarily seen as more loyal than nontelecommuters. From a managerial perspective, telecommuting does not impact severely on the management ability of line managers and does not require significantly more supervisory oversight, time, or monitoring than required for nontelecommuters. Finally, line managers were of the opinion that telecommuters are readily available and that their absence from the office does not have any significant impact on the workload of nontelecommuters. 


\section{Student Satisfaction with Telecommuting and Nontelecommuting Academics}

This section reflects on the outcome of research findings among the 156 students evaluating a total of 97 different modules lectured by telecommuting and nontelecommuting academics. It is important to note that a filter question was used to determine whether students had made any academic enquiries. This precondition served as qualifier to allow students to participate and rate the groups on 17 predetermined academic support criteria where $1=$ extremely dissatisfied and $7=$ extremely satisfied. The information contained in Table 9 presents a holistic comparison between the student satisfaction ratings for the two academic groups.

Table 9

Student Satisfaction Rating of Academic Groups

\begin{tabular}{|l|l|l|l|}
\hline \multirow{2}{*}{ Statement } & $\begin{array}{l}\text { Telecommuting } \\
\text { academics }\end{array}$ & $\begin{array}{l}\text { Nontelecommuting } \\
\text { academics }\end{array}$ & Total \\
\cline { 2 - 4 } & Mean & Mean & Mean \\
\hline $\begin{array}{l}\text { Availability / ease of getting hold of } \\
\text { lecturer(s) via myUnisa }\end{array}$ & 4.06 & 3.96 & 4.03 \\
\hline $\begin{array}{l}\text { Availability / ease of getting hold of } \\
\text { lecturer(s) via email }\end{array}$ & 4.24 & 4.04 & 4.17 \\
\hline $\begin{array}{l}\text { Availability / ease of getting hold of } \\
\text { lecturer(s) via telephone }\end{array}$ & 3.85 & 3.94 & 3.88 \\
\hline Available time & 4.32 & 4.24 & 4.29 \\
\hline Enthusiasm & 4.68 & 4.30 & 4.53 \\
\hline Approachability & 4.81 & 4.57 & 4.73 \\
\hline Extent of support & 4.75 & 4.52 & 4.66 \\
\hline Promptness in handling enquiries & 4.66 & 4.44 & 4.58 \\
\hline Encouraging effective learning & 4.89 & 4.12 & 4.60 \\
\hline Punctuality & 4.47 & 4.28 & 4.40 \\
\hline Reliability & 4.52 & 4.29 & 4.44 \\
\hline Understanding of subject matter & 5.15 & 4.46 & 4.89 \\
\hline Willingness to answer queries & 5.04 & 4.68 & 4.90 \\
\hline Politeness & 5.07 & 4.70 & 4.94 \\
\hline Ability to inspire & 4.78 & 4.13 & 4.54 \\
\hline Helpfulness & 4.79 & 4.41 & 4.63 \\
\hline Efficiency & 4.67 & 4.26 & 4.51 \\
\hline Average & 4.63 & 4.31 & 4.51 \\
\hline
\end{tabular}

Although both academic groups show above-average ratings for all items, it is clear from Table 9 that student satisfaction with telecommuter academics is higher for all except 
one of the evaluation criteria (availability/ ease of getting hold of your lecturer(s) via telephone). To establish whether the differences between the rating scores for the two professor groups are statistically significant, an analysis of variance (ANOVA) test was conducted. The outcome of this test showed statistically significant differences only for the following items:

- $\quad$ encouraging effective learning $(p<0.05$, Sig $=0.013)$;

- understanding of subject matter $(p<0.05, \mathrm{Sig}=0.025)$;

- $\quad$ ability to inspire you ( $p<0.05, \operatorname{Sig}=0.036)$.

Against this background, it can be concluded at a 95\% level of confidence that telecommuting academics are more effective in encouraging learning and have a better understanding of subject matter and ability to inspire students. This outcome is to be expected as only academics at professor and associate professor levels with at least three years' work experience qualified to telecommute at Unisa during the telecommuting trial period.

\section{Conclusions and Recommendations}

The key findings and trends emerging from the Unisa telecommuting baseline study provide sound motivation to expand telecommuting practices at open distance higher education institutions. This recommendation is also supported by the work of Bélanger (1999), Pinsonneault and Boisvert (2001), and Potter (2003) that identified improved productivity, loyalty, job satisfaction, flexibility, employee morale, retention and attraction as major reasons for the international growth in telecommuting. Key challenges that will most likely be faced by open distance higher education institutions include the following:

- Establishing concrete and well communicated goals for telecommuters that will obviate management practices such as direct and consistent observation of employees to determine their productivity and provide clarity for employees WFH regarding precise expectations.

- Negotiating flexible work arrangements with only those employees that institutions confidently regard as responsible enough to telecommute. In this regard, a well-crafted telecommuting programme that will assist employers and employees to determine whether remote work is appropriate for a given job title or person is required.

- Develop strategies to remain in virtually constant contact with telecommuting employees. Managers should encourage telecommuters to take the initiative by communicating with nontelecommuters and establish guidelines for telecommuters to communicate at regular intervals with the office.

- Reduce the burden on nontelecommuting co-workers and minimise loss of productivity; managers should state and enforce in agreements/policies that 
telecommuters must attend job-related meetings, training sessions and conferences. Managers need to inform nontelecommuters of telecommuters' availability schedule and contact information and any anticipated job responsibility changes in the absence of telecommuting co-workers.

- Management should minimise or prevent having the nontelecommuter take on additional workloads. However, if this is inevitable, then the days the telecommuter is at the office, the nontelecommuter could be given relief and the telecommuter could take on some of the nontelecommuter's additional tasks.

- Create the required computer setups and equipment for telecommuters alongside establishing a system to address the ergonomics in remote and home offices (also see Ellison, 2012).

- Eligibility needs to be established and future telecommuting policies should also address liability, homeowners and liability insurance, security (both data and employee), telephone and data connections, and how equipment and supplies will be provided.

- Proper training in the administration and implementation of the telecommuting programmes. Managers may also need to be trained in monitoring, supervising, and measuring and evaluating performance.

Higher distance education institutions have clearly become part of the transformation to introduce telecommuting and this practice is likely to expand further given the positive perceptions and emotional impact of telecommuting and the fact that such practices could turn out to be highly productive. Against this background it is important that practitioners and researchers need to continuously examine how the implementation of a telecommuting programme affects all parties, not only the telecommuters. This is precisely what the Unisa telecommuting baseline study has achieved and it is anticipated that these findings will better inform open distance higher education institutions of the factors and issues that interplay in the dynamics of the telecommuting arrangement and how to increase the effectiveness of their telecommuting programme to the benefit of all stakeholder groups. 


\section{References}

Alvi, S., \&McIntyre, D. (1993). The open collar worker. Canadian Business Review, 20(1), 21-24.

Apgar, M. V. (1998). The alternative workplace: Changing where and how people work. Harvard Business Review, May-June, 121-136.

Baig, E. C. (1995). Welcome to the officeless office: Telecommuting may finally be out of the experimental stage. Business Week, J une 26, 104-106.

Bailey, D. E., \& Kurland, N. B. (2002). A review of telework research: Findings, new directions, and lessons for the study of modern work. J ournal of Organizational Behavior, 23(4), 383-400.

Barthel, M. (1995). Telecommuting finding a home at banks. American Banker, 16, February 1.

Baruch, Y., \& Nicholson, N. (1997). Home, sweet work: Requirements for effective home working. J ournal of General Management, 23(2), 15-30.

Brown, J . M. C. (2010). Telecommuting: The affects and effects on nontelecommuters. Dissertation submitted to the Faculty of Virginia Polytechnic Institute and State University, Falls Church, Virginia. (18 March.)

Caudron, S. (1992). Working at home pays off. Personnel J ournal, November, 40-49.

Chapman, A.J ., Sheehy, N. P., Heywood, S., Dooley, B., \&Collins, S. C. (1995). The organizational implications of teleworking. In C. L. Cooper, \& I.T. Robertson, (Eds.), International review of industrial and organizational psychology (pp. 229-248). New York, NY: J ohn Wiley and Sons.

Christensen, K. E. (1992). Managing invisible employees: How to meet the telecommuting. Employment Relations Today, Summer, 133-143.

Côté-O'Hara, J . (1993). Sending them home to work: Telecommuting. Business Quarterly, 57(3), 104-109.

Cooper, C., \& Kurland, N. B. (2002). Telecommuting, professional isolation and employee development in public and private organizations. J ournal of Organizational Behavior, 23(4), 511-532.

Cross, T. B., \& Raizman, M. (1986). Telecommuting: The future technology of work. Homewood, IL: Dow J ones-Irwin. 
Davenport, T. H., \& Pearlson, K. (1998). Two cheers for the virtual office. Sloan Management Review, 39(4), 51-65.

Department of Higher Education and Training. (2012). Green paper for post-school education and training. Pretoria. (J anuary.)

DeSanctis, G. (1984). Attitudes towards telecommuting: Implications for work at home programs. Information and Management, 7(3), 133-139.

DHET, see Department of Higher Education and Training.

Di Martino, V., \&Wirth, L. (1990). Le télétravail, un nouveau mode de travail et de vie. Revue Internationale du Travail, 129(5), 585-611.

Doswell, A. (1992). Home alone? - Teleworking. Management Services, October, 18-21.

Duxbury, L., \& Higgins, C. (1995). Rapport sommaire sur le projet-pilote de télétravail de Statistiques Canada. Canada: Statistics Canada. (J anuary, Document \# 75F0008XPF.)

Duxbury, L., \&Neufield, D. (1999). An empirical evaluation of the impacts of telecommuting on intra-organizational communication. J ournal of Engineering and Technology Management, 16(1), 1-28.

Eldib, O. E., \& Minoli, D. (1995). Telecommuting. Boston, MA: Artech House.

Ellison, J . K. (2012). Ergonomics for telecommuters \& other remote workers. Des Plaines, United States: American Society of Safety Engineers.

Federal Communications Commission. (2003). Report on supervisor/ manager telecommuting survey. Audit Report no 03-AUD-09-17. (25 November.)

Fitzer, M. M. (1997). Managing from afar: Performance and rewards in a telecommuting environment. Compensation and Benefits Review, 29(1), J anuary-February, 65-73.

Fritz, M. B. W., Narasimhan, S., \& Rhee, H. K. (1998). Communication and coordination in the virtual office. J ournal of Management Information Systems, 14(4), 7-28.

Froggatt, C. C. (1998). Telework: Whose choice is it anyway? Facilities Design and Management, Spring, 18-21. 
Golden, T. (2007). Co-workers who telework and the impact on those in the office: Understanding the implications of virtual work for co-worker satisfaction and turnover intentions. Human Relations, 60(11), 1641-1667.

Gordon, G. E., \& Kelly, M. M. (1986). Telecommuting: How to make it work for you and your company. Englewood Cliffs, N.J : Prentice Hall.

Gordon, G. (2006). HP downshifts telecommuting. Retrieved from http:// www.workforce.com/ section/00/article/ 24/42/47.html

Gray, M., Hodson, N., \& Gordon, G. (1993). Teleworking explained. Chichester, West Sussex, England: J ohn Wiley and Sons.

Greengard, S. (1995). All the comforts of home. Personnel J ournal, 74, 104-108.

Guimaraes, T., \&Dallow, P. (1999). Empirically testing the benefits, problems, and success factors for telecommuting programs. European J ournal of Information Systems, 8, 40-54.

Hamilton, C. A. (1987). Telecommuting. Personnel J ournal, April, 91-101.

Harrington, S. J ., \& Ruppel, C. P. (1999). Telecommuting: A test of trust, competing values, and relative advantage. IEEE Transactions on Professional Communication, 42(4), 223-239.

Huws, U. (1984). The new homeworkers: New technology and the changing location of white-collar work. London, UK: Low Pay Unit.

Igbaria, M. (1998). The virtual workplace (electronic book). Hershey, PA: Idea Group Publishing.

Ipsos. (2011). Telecommuting: How often do you currently telecommute with your work? Global@dvisory, (G@26). November.

J ohnson, M. (1997). Teleworking.. in brief. Oxford, UK: Butterwoth-Heinemann.

Katz, A. I. (1987). The management, control, and evaluation of a telecommuting project: A case study. Information and Management, 13, 179-1190.

Kinsman, F. (1987). The telecommuters. Chichester, England: J ohn Wiley and Sons.

Kirkley, J . (1994). Business week's conference on the virtual office. Business Week, September 5, 63-66. 
Kline, P. (1999). The handbook of psychological testing (2nd ed). London: Routledge.

Korzeniowski, P. (1997). The telecommuting dilemma. Business Communications Review, April, 29-32.

Kraut, R. E. (1987). Predicting the use of technology: The case of telework. In R. E. Kraut (Ed.), Technology and the transformation of white-collar work (pp.113133). Hillsdale, New J ersey: Lawrence Erlbaum Associates.

Kugelmass, J . (1995). A manager's guide to flexible work arrangements. Lexington, MA: Lexington Books.

Mahfood, P. E. (1992). Home work: How to hire, manage and monitor employees who work at home. Chicago, Ill: Probus Publishing Company.

Martinez, J . G. (2004). The effects of telecommuting on attitudinal and behavioural characteristics of organisational culture. Focus III, 1, 19-34.

McCloskey, D. W., \& Igbaria, M. (2003). Does 'out of sight' mean 'out of mind'? An empirical investigation of the career advancement prospects of telecommuters. Information Resources Management J ournal, 16(2), 19-35.

McCune, J . C. (1998). Telecommuting revisited. Management Review, February, 1016.

Mid-America Regional Council. (2013). Common questions about telecommuting. Retrieved from http:// www.marc.org/ rideshare/ telecommutefaq.htm

Ng, C. F. (2006). Academics telecommuting in open and distance education universities: Issues, challenges, and opportunities. The International Review of Research in Open and Distance Learning, 7(2). Retrieved from http:// www.irrodl.org/index.php/ irrodl/article/ view/300/632.

Nilles, J. M. 1975. Telecommunications and organisational decentralisation. IEEE Transactions on Communications, 23, 1142-1147.

Nilles, J . M. (1994). Making telecommuting happen: A guide for telemarketers and telecommuters. New York: Van Nostrand Reinold.

Nunnaly, J . (1978). Psychometric theory. New York: McGraw-Hill. 
Olson, M. H. (1987a). Telework: Practical experience and future prospects. In R. E. Kraut (Ed.), Technology and the transformation of white-collar work (pp. 135152). Hillsdale, NJ : Lawrence Erlbaum Associates.

Olson, M. H. (1987b). An investigation of the impact of remote work environment and supporting technology. New York: New York University. (Working paper, Center of Research on Information Systems.)

Olson, M. H. (1988). Organizational barriers to telecommuting. In W. B. Korte, B. Steinle, \& S. Robinson, (Eds.), Telework: Present situation and future development of a new form of work organization (pp. 77-100). Amsterdam: North-Holland.

Pinsonneault, A., \& Boisvert, M. (1999). The impacts of telecommuting on organizations and individuals: A review of the literature. Retrieved from http:// expertise.hec.ca/gresi/ wpcontent/uploads/2013/02/ cahier9909.pdf

Pinsonneault, A., \& Boisvert, M. (2001). The impacts of telecommuting on organizations and individuals: A review of the literature. In N.J J J ohnson, (Ed.), Telecommuting and virtual offices: Issues and opportunities (pp. 163185). Hershey, P. A.: Idea Group Publishing.

Potter, E. (2003). Telecommuting: The future of work, corporate culture, and American society. J ournal of Labor Research, 23(1), 73-83.

Pratt, J . (1984). Home teleworking: A study of its pioneers. Technological Forecasting and Social Change, 25, 1-14.

Psikurich, G. M. (1996). Making telecommuting work. Training and Development, February, 22.

Ramsower, R. M. (1985). Telecommuting: The organizational and behavioral effects of working at home. Ann Arbor, MI: UMI Research Press.

Reinsch, N. L. Jr. (1997). Relationship between telecommuting workers and their managers: An exploratory study. The J ournal of Business Communications, 34(4), 343-369.

Richter, J ., \& Meshulam, I. (1993). Telework at home: The home and the organization perspective. Human Systems Management, 12, 193-203. 
Ruppel, C. P., \& Harrington, S. J . 1995. Telework: Innovation where nobody is getting on the bandwagon. Data Base Advances, 26(2-3), 87-104.

Solomon, N. A., \& Templer, A. J . (1993). Development of non-traditional work sites: The challenge of telecommuting. J ournal of Management Development, 12(5), 21-32.

TeamViewer ${ }^{\circledR}$. (2012, April). Telecommuting for earth survey by uSamp. Germany. Retrieved from http:/ / www.gfi.com/ blog/ survey-americans-stress-benefitsand-demands-of-telecommuting-infographic/

Trembly, A. C. (1998). Telecommuting productively. Beyond Computing, 7(4), 42-44.

Unisa, see University of South Africa.

University of South Africa. (2011). Directive: Professors working from home. Unisa.

University of South Africa. (2013). The leading ODL university. Retrieved from http:// www.unisa.ac.za/ Default.asp?Cmd=ViewContent\&ContentID=1776 $\underline{5}$

Weiss, J . M. (1994). Telecommuting boosts employee output. HR Magazine, 39, 51-53.

Wikipedia. (2013). Telecommuting. (November.) Retrieved from http:// en.wikipedia.org/wiki/ Telecommuting

Wilkes, R. B., Frolick, M. N., \& Urwiler, R. (1994). Critical issues in developing successful telework programs. J ournal of Systems Management, 45, 30-34.

Xenakis, J .J . (1997). Workers in the world disperse! CFO, 13(10), 79-85.

Yamini, F., Balakrishnan, H., Nguyen, G., \& Lopez, X. (1997). Real-time collaborative technologies: Incentives and impediments. (3 April.) Berkley: University of California. Retrieved from http:// wwwinst.eecs.berkeley.edu/ eecsba1/ sp97/ reports/ eecsba1d/report/

Yick, A. G., Patrick, P., \& Costin, A. (2005). Navigating distance and traditional higher education: Online faculty experiences. The International Review of Research in Open and Distance Learning, 6(2). Retrieved from http:// www.irrodl.org/index.php/irrodl/article/ viewArticle/ 235/320 